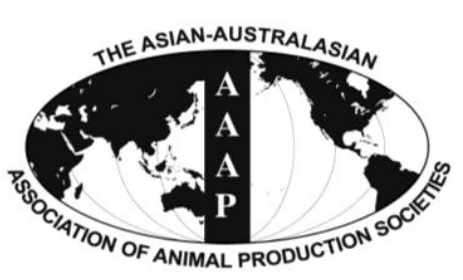

Open Access

Asian Australas. J. Anim. Sci.

Vol. 27, No. 10 : 1452-1460 October 2014

http://dx.doi.org/10.5713/ajas.2014.14085

www.ajas.info

pISSN 1011-2367 elSSN 1976-5517

\title{
Nutritional Evaluation of Young Bulls on Tropical Pasture Receiving Supplements with Different Protein:Carbohydrate Ratios
}

\author{
E. E. L. Valente*, M. F. Paulino ${ }^{1}$, L. V. Barros $^{2}$, D. M. Almeida ${ }^{1}$, L. S. Martins ${ }^{1}$, and C. H. A. Cabral ${ }^{3}$ \\ Department of Animal Science, Universidade Estadual do Oeste do Paraná, \\ Marechal Cândido Rondon, PR 85960-000, Brazil
}

\begin{abstract}
The objective of this work was to evaluate the nutritional parameters of young bulls supplemented with different ratios of protein: carbohydrate on tropical pastures from 4 until 18 months old. Fifty-five non-castrated beef calves $(138.3 \pm 3.4 \mathrm{~kg}$, 90 to $150 \mathrm{~d}$ of age) were used. The calves (young bulls) were subjected to a 430-d experimental period encompassing 4 seasons. The treatments were as follows: control, only mineral mixture; HPHC, high protein and high carbohydrate supplement; HPLC, high protein and low carbohydrate supplement; LPHC, low protein and high carbohydrate supplement; and LPLC, low protein and low carbohydrate supplement. The amount of supplement was adjusted every $28 \mathrm{~d}$. Dry matter (DM) intake was higher in the dry-to-rainy transition and rainy seasons for all nutritional plans. Non-supplemented animals had lower intakes of DM and total digestible nutrients (TDN) than supplemented young bulls in all seasons. Although differences in DM intake were not observed between supplemented animals, the supplements with high carbohydrate (HPHC and LPHC) had lower forage intake during suckling (rainy-to-dry transition season) and in the rainy season. However, the HPHC treatment animals had higher intake and digestibility of neutral detergent fiber. It can be concluded that supplementation with high protein levels (supplying 50\% of the crude protein requirement) provide the best nutritional parameters for grazing young bulls in most seasons, increasing intake and digestibility of diet, and these effects are more intense when associated with high carbohydrate levels level (supplying 30\% TDN requirement). (Key Words: Digestibility, Grazing, Intake, Pasture, Supplementation, Calf)
\end{abstract}

\section{INTRODUCTION}

Feed intake by ruminants is complex; integrated mechanisms have been proposed that consider multifactorial view, including factors associated with minimization of animal discomfort (Forbes, 2007). Due to the complexity and difficulty measuring the intake by beef cattle, few studies have been carried out on tropical pasture, and the results obtained until now have been inconclusive.

\footnotetext{
* Corresponding Author: Eriton Egidio Lisboa Valente.

E-mail: eritonvalente@yahoo.com.br

${ }^{1}$ Department of Animal Science, Universidade Federal de Viçosa, Viçosa, MG 36570-000, Brazil.

${ }^{2}$ Department of Animal Science, Universidade Estadual do Mato Grosso, Cacéres, MT 78200-000, Brazil.

${ }^{3}$ Department of Animal Science, Universidade Federal do Mato Grosso, Rondonópolis, MT 78700-075, Brazil.

Submitted Feb. 5, 2014; Revised Apr. 1, 2014; Accepted Apr. 28, 2014
}

Dietetic protein has been the main factor that limits utilization of tropical pasture by beef cattle in the dry season (Goes et al., 2010; Valente et al., 2011a) when the dormancy stage of plants decreases the protein content of pasture. However, several researchers have also found improvement of nutritional characteristics with protein supplementation in the rainy season (Goes et al., 2010; Valente et al., 2011a), even in plants at the vegetative stage, due to the association of protein with fiber (Costa et al., 2011), decreasing the availability of protein to ruminal microorganisms and to animals.

The ratio of protein:carbohydrate in a supplement determines the interactive effects on intake and digestibility of diet (Souza et al., 2010). However, the intensity of these effects is determined by the composition of that basal diet (pasture), which fluctuates throughout the seasons. The supplementation may increase the availability of energy and protein to animals by improvement of ruminal conditions 
and greater extraction of energy and nutrients from pasture and/or directly supplied by grains to animal metabolism (Valente et al., 2011a).

There is little research that has evaluated beef cattle throughout productive cycle on tropical pasture or that compare the use of supplements between seasons. The lack of information about the nutritional characteristics (feed intake and digestibility) throughout production cycle has limited the application of technology developed in research conditions by commercial systems of production. Thus, the objective of this research was to evaluate nutritional parameters of young bulls supplemented with different ratios of protein: carbohydrate on tropical pastures from 4 until 18 months.

\section{MATERIAL AND METHODS}

The experimental protocol and procedures were approved by the Universidade Federal de Viçosa Animal Care and Use Committee. This experiment was carried out at the beef cattle facility of the Universidade Federal de Viçosa, in Viçosa, MG, Brazil (20 $\left.45^{\prime} \mathrm{S} 42^{\circ} 52^{\prime} \mathrm{W}\right)$. The experimental area is located in a hilly area at an altitude of $670 \mathrm{~m}$. This study was carried out between March of 2010 and April of 2011. The weather data are presented in Figure 1.

Fifty-five non-castrated beef calves (young bulls) with average initial body weights of $138.3 \pm 3.4 \mathrm{~kg}$ and between 90 and $150 \mathrm{~d}$ of age and their dams (30, Nellore; 10, $1 / 2$ Nellore and 1/2Holstein; $15,3 / 4$ Nellore and 1/4Holstein) were used. Only Nellore sires were used in this study. Two young bulls from each treatment at the end of phase 1 and one young bull from each treatment at the end of phases 2 and 3 were randomly withdrawn from their groups to realize other studies.

The calves were submitted to a period of $15 \mathrm{~d}$ of

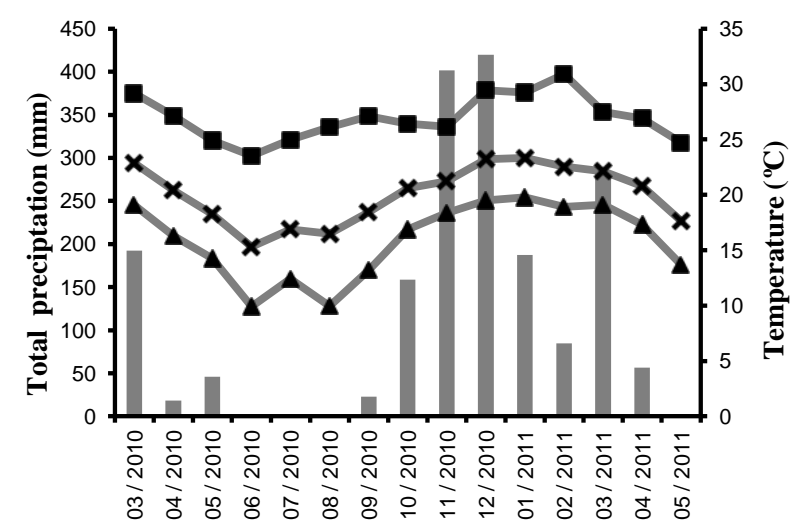

Preciptation $-\boldsymbol{x}$ Average T. $\longrightarrow$ MaximumT. $\longrightarrow$ Minimum T.

Figure 1. Precipitation, average temperature (Average T), maximum temperature (Maximum $\mathrm{T}$ ) and minimum temperature (Minimum T) during the experimental period. adaptation and a 430-d experimental period divided into four phases: phase 1, suckling phase in the rainy-dry transition season (112 d); phase 2, post-weaning in the dry season (84 d); phase 3 , post-weaning in the dry-rainy transition season ( $84 \mathrm{~d}$ ); and phase 4 , fattening phase in the rainy season $(150 \mathrm{~d})$.

The animals were kept in 10-ha paddocks of Signal Grass (Brachiaria decumbens) in phase 1 and in 2.5-ha in the other phases, provided with privative feeders for calves (0.5 m per calf) in phase 1 and conventional feeders $(0.7 \mathrm{~m}$ per young bull) in the other phases, and drinkers. The nutritional plans (treatments), which were randomly assigned to the young bulls, were as follows: control, received mineral mixture only; HPHC, high protein and high carbohydrate supplement; HPLC, high protein and low carbohydrate supplement; LPHC, low protein and high carbohydrate supplement; and LPLC, low protein and low carbohydrate supplement (Table 1). Approximately 50\% and $25 \%$ of the protein requirement were supplied in the high and low protein supplements, respectively, and about $30 \%$ and $15 \%$ of the total digestible nutrients (TDN) requirements were supplied in the high and low carbohydrate supplements, respectively. Half of the stipulated requirements were supplied by the supplement in phase 1 due to the milk intake. The amount of supplement was adjusted every $28 \mathrm{~d}$ by using the estimated protein and energy requirement of beef cattle in tropical conditions (Valadares et al., 2006), with the weight gain in the adaptation period to first adjustment of the supplementation and the previous 28-d weight gain to adjust in the other periods. Therefore, HPHC supplied $50 \%$ of crude protein (CP) requirement and $30 \%$ of TDN requirement, HPLC supplied $50 \%$ of $\mathrm{CP}$ requirement and $15 \%$ of TDN requirement, LPHC supplied $25 \%$ of $\mathrm{CP}$ requirement and $30 \%$ of TDN requirement and LPLC supplied $25 \%$ of CP requirement and $15 \%$ of TDN requirement.

The supplement composition was formulated for all

Table 1. Composition of supplement (as-fed basis)

\begin{tabular}{lccccc}
\hline & \multicolumn{5}{c}{ Nutritional plan } \\
\cline { 2 - 6 } & Control & HPHC & HPLC & LPHC & LPLC \\
\hline Corn & - & 55.0 & 0.0 & 83.5 & 53.0 \\
Corn gluten & - & 3.0 & 20.0 & 0.0 & 14.0 \\
Soybean meal & - & 37.0 & 70.0 & 12.0 & 24.0 \\
Urea/ AS & - & 1.0 & 2.0 & 0.5 & 1.0 \\
$\mathrm{MM}^{3}$ & 100 & 4.0 & 8.0 & 4.0 & 8.0 \\
\hline
\end{tabular}

${ }^{1}$ HPHC, high protein and high carbohydrate supplement; HPLC, high protein and low carbohydrate supplement; LPHC, low protein and high carbohydrate supplement; LPLC, low protein and low carbohydrate supplement; AS, ammonia sulfate; MM, mineral mixture.

${ }^{2}$ Urea+ammonia sulfate $(9: 1)$.

${ }^{3}$ Composition: calcium, 8.7\%; phosphor, 9.0\%; sulfur, 9.0\%; sodium, $18.7 \%$; zinc, $2,400.00 \mathrm{mg} / \mathrm{kg}$; copper, $800.00 \mathrm{mg} / \mathrm{kg}$; manganese, $1,600.00 \mathrm{mg} / \mathrm{kg}$; iodine, $40.00 \mathrm{mg} / \mathrm{kg}$; cobalt, $8.00 \mathrm{mg} / \mathrm{kg}$; selenium, 8.16 $\mathrm{mg} / \mathrm{kg}$. 
supplements that have a similar protein profile with same proportion of protein from each ingredient (similar proportion of protein from corn, soybean meal and urea; Table 2). The calves were supplemented once a day at 11 am. In order to minimize the possible effects of paddocks on experimental treatments, the animals were rotated among the five paddocks every seven days, allowing each group to stay in each paddock for the same period of time and intake similar pasture; therefore, their diets differed only by the supplement intake. The calves were weaned after the end of phase 1 , when they were about eight months old, $112 \mathrm{~d}$ after the beginning of the experimental period.

Forage samples were randomly taken, every $28 \mathrm{~d}$, in order to evaluate the forage mass per hectare. In each paddock, six forage samples were randomly selected by using a metal square $(0.5 \times 0.5 \mathrm{~m})$, and they were cut approximately $1 \mathrm{~cm}$ above the soil and subsampled (200 g). In addition, pasture samples were taken with the handleplucking method every seven days to evaluate chemical composition of the forage intake. All pasture samples were dried at $60^{\circ} \mathrm{C}$ for 72 hours and were ground sufficiently to pass through a 1-mm screen sieve. The handle-plucking samples were proportionally sub-sampled to create a composite sample per period ( $28 \mathrm{~d})$.

In order to evaluate forage intake and digestibility, trials (nine days) were performed by using all young bulls in middle of each phase. Fecal dry matter (DM) excretion was determined by using chromic oxide as an external marker in the amount of $10,12,14$, and $16 \mathrm{~g} / \mathrm{d}$ to phases $1,2,3$, and 4 , respectively. These portions were packaged in a paper cartridge and directly introduced into the esophagus through a rubber tube. The animals received the marker once daily at 11 am during the first eight days of the digestion trial. To evaluate individual intake of supplement, 10, 12, 14, and 16 $\mathrm{g} / \mathrm{d}$ of titanium dioxide were mixed with the supplement and offered to animals in phases $1,2,3$, and 4, respectively. The forage intake was estimated by using indigestible neutral detergent fiber (iNDF) as an internal marker. After five days of adaptation, fecal samples were collected at 3 pm on day 7, at 11 am on day 8 , and at 7 am on day 9 of the digestion trial period. The fecal samples were dried at $60^{\circ} \mathrm{C}$ for 72 hours, ground to pass through a 1-mm screen sieve and proportionally sub-sampled to create a composite sample by phase.

Milk intake by calves was estimated on days 28,56 , and 84 of the experimental period (phase 1). Cows were separated from their calves at $6 \mathrm{pm}$. At 6 am of the next day, cows were milked immediately after an injection of $2 \mathrm{~mL}$ of oxytocin (10 IU/mL; Ocitovet, Paulínia, SP, Brazil) in the mammary vein, and the produced milk was weighed. The milking was planned so that all cows were milked with 2 hours. The exact time when each cow was milked was recorded, and the milk production was converted to a 24hour production. The milk produced was corrected to $4 \%$ fat ( $4 \%$ fat-milk) calculated by the following equation:

$$
\begin{aligned}
& 4 \% \text { fat-milk }(\mathrm{kg}) \\
& =0.4 \times(\text { milk production }) \\
& +[15 \times(\text { fat production } \times \text { milk production } / 100)]
\end{aligned}
$$

After a 16-h fast, the animals were weighed at the beginning and end of each phase. Samples of forage, feces and supplement ingredients were analyzed for DM (index no. 920.39), CP (index no. 954.01), organic matter (index no. 942.05), and ether extract (index no. 920.39) as described by AOAC (Association of Official Analytical Chemists, 1990). Lignin content was obtained by cellulose solubilization in sulfuric acid (Van Soest and Robertson, 1985). For analysis of neutral detergent fiber (apNDF), samples were treated with thermostable $\alpha$-amylase without sodium sulfite and corrected for ash residue (Mertens, 2002) and residual nitrogen compounds (Licitra et al., 1996). The iNDF content (used as internal marker) in feed and fecal samples was evaluated using F57 (Ankom, Macedon, NY, USA) bags incubated in rumen by $288 \mathrm{~d}$

\begin{tabular}{|c|c|c|c|c|c|c|c|c|}
\hline & \multicolumn{4}{|c|}{ Supplement } & \multicolumn{4}{|c|}{ Pasture $^{1}$} \\
\hline & HPHC & HPLC & LPHC & LPLC & Phase 1 & Phase 2 & Phase 3 & Phase 4 \\
\hline Dry matter & 87.1 & 89.5 & 85.8 & 87.0 & 29.6 & 42.5 & 28.0 & 21.3 \\
\hline Organic matter & 89.3 & 87.4 & 88.4 & 85.8 & 91.4 & 92.4 & 92.4 & 91.5 \\
\hline Crude protein & 29.2 & 55.3 & 15.4 & 29.5 & 8.8 & 5.5 & 12.1 & 10.7 \\
\hline apNDF & 8.7 & 10.2 & 7.4 & 9.2 & 65.3 & 65.0 & 61.5 & 61.6 \\
\hline Ether extract & 2.6 & 1.5 & 3.0 & 2.4 & 1.2 & 1.2 & 1.5 & 1.2 \\
\hline $\mathrm{CNF}$ & 46.2 & 23.3 & 57.2 & 43.6 & 16.1 & 20.7 & 17.3 & 17.9 \\
\hline Lignin & 0.4 & 0.8 & 0.2 & 0.3 & 4.9 & 4.4 & 3.6 & 2.7 \\
\hline
\end{tabular}
(Valente et al., 2011b). Additionally, fecal samples were

Table 2. Chemical composition of supplement and pasture (\% DM basis)

HPHC, high protein and high carbohydrate supplement; HPLC, high protein and low carbohydrate supplement; LPHC, low protein and high carbohydrate supplement; LPLC, low protein and low carbohydrate supplement; apNDF, neutral detergent fiber corrected for ash and protein; CNF, non-fibrous carbohydrates; Lignin, corrected for ash.

${ }^{2}$ Obtained by handle plucked sampling; Phase 1 = suckling phase in rainy-dry transition season (112 d); Phase 2 = post-weaning in dry season ( $\left.84 \mathrm{~d}\right)$; Phase 3 = post-weaning in the dry-rainy transition season ( $84 \mathrm{~d})$; Phase 4 = finishing phase in the rainy season $(150 \mathrm{~d})$. 
evaluated for chromium and titanium dioxide content by using atomic absorption and colorimetric methods, respectively. Forage samples cut $1 \mathrm{~cm}$ above soil level were analyzed for DM, as previously described. Milk was analyzed for protein, fat, lactose and total solids content using spectroscopy (Foss MilkoScan FT120, Hillerød, Denmark).

The fecal excretion was estimated by ratio of the marker dose (chromic oxide) and its concentration in the feces. Dry matter intake (DMI) was estimated by using the iNDF as an internal marker and calculated by the following equation:

$$
\begin{aligned}
\text { DMI }(\mathrm{kg} / \mathrm{d})=\{ & {[\text { ( }} \\
& \text { FExiNDF feces })-\mathrm{iNDF} \text { supplement }] \\
& \text { iNDF forage }\}+ \text { SI }+ \text { MI }
\end{aligned}
$$

where, FE is the fecal excretion ( $\mathrm{kg} / \mathrm{d})$, iNDF feces is the concentration of iNDF in the feces $(\mathrm{kg} / \mathrm{kg})$, iNDF supplement is the iNDF in the supplement $(\mathrm{kg})$, iNDF forage is the concentration of iNDF in forage $(\mathrm{kg} / \mathrm{kg})$, and $\mathrm{SI}$ is the supplement intake and MI is the milk intake.

The estimation of the individual intake of the supplement was obtained with the external marker titanium oxide using the following equation:

$$
\mathrm{SI}=(\mathrm{FE} \times \mathrm{MCF}) / \mathrm{MCS}
$$

where SI is the DM supplement intake $(\mathrm{kg} / \mathrm{d}), \mathrm{FE}$ is the fecal excretion $(\mathrm{kg} / \mathrm{d}), \mathrm{MCF}$ is the marker concentration in the feces $(\mathrm{kg} / \mathrm{kg})$, and MCS is the marker concentration in the supplement $(\mathrm{kg} / \mathrm{kg})$.

This study was carried out using a completely randomized design using a $2 \times 2+1$ factorial arrangement to evaluate the nutritional plans ( 2 protein levels, 2 carbohydrate levels and 1 control). The variables were evaluated according to a completely random design in repeated measures over time design by using mixed models method according to the model (Kaps and Lamberson, 2004):

$$
Y_{i j k}=\mu+P_{i}+a_{i j}+F_{j}+(P \times F)_{i j}+\varepsilon_{i j k}
$$

where, $Y_{\mathrm{ijk}}$ is the response variable measured in the experimental unit $\mathrm{k}$ submitted to the nutritional plan $\mathrm{i}$ in the $\mathrm{j}$ phase, $\mu$ is the overall constant, $\mathrm{Pi}$ is the effect of the $\mathrm{i}$ nutritional plan (fixed effect), $\mathrm{a}_{\mathrm{ij}}=$ effect of animal $\mathrm{j}$ within nutritional plan $i$ (random effect), $F_{j}$ is the effect if $j$ performance phase (fixed effect), $(\mathrm{P} \times \mathrm{F})_{\mathrm{ij}}$ is the interaction between the principal effects (fixed effect), and $\varepsilon_{\mathrm{ijk}}$ is the non-observable random error, presupposed with normal distribution.

The best structures of the matrix of (co)variance were defined using the Akaike's information criteria. Significant difference was considered at $\mathrm{p}<0.05$. The data were analyzed by using the MIX procedure of SAS, version 9.1 (SAS Institute, Cary, NC, USA).

\section{RESULTS}

The annual precipitation was about $1,500 \mathrm{~mm}$, which $90 \%$ occurred from October through March (Figure 1). Average forage mass throughout the experimental period was $3.88,3.89,3.06$, and $3.18 \mathrm{t} / \mathrm{ha}$ in phases $1,2,3$, and 4 , respectively. The $\mathrm{CP}$ of forage was affected by season, with $8.8,5.5,12.1$, and $10.7 \% \mathrm{CP}$ in phases $1,2,3$, and 4 , respectively (Table 2). Moreover, about $25 \%$ of $\mathrm{CP}$ was associated with fiber, being slowly available to ruminal microorganisms.

The young bulls had greater $(\mathrm{p}<0.05)$ average daily weight gain (ADG) in phases 1 and 4 (rainy seasons). Nonsupplemented young bulls (control) had lower $(\mathrm{p}<0.05)$

\begin{tabular}{|c|c|c|c|c|}
\hline \multirow{2}{*}{ Nutritional plan } & \multicolumn{4}{|c|}{ Production phase } \\
\hline & Phase 1 & Phase 2 & Phase 3 & Phase 4 \\
\hline \multicolumn{5}{|c|}{ Initial body weight (kg) } \\
\hline Control & $138.2 \pm 8.3$ & $209.1 \pm 8.6$ & $219.1 \pm 9.8$ & $251.6 \pm 11.4$ \\
\hline HPHC & $138.1 \pm 8.5$ & $234.1 \pm 8.7$ & $273.9 \pm 11.0$ & $319.6 \pm 13.0$ \\
\hline HPLC & $137.3 \pm 7.9$ & $230.1 \pm 9.9$ & $265.4 \pm 10.4$ & $301.5 \pm 11.9$ \\
\hline LPHC & $138.4 \pm 8.3$ & $234.4 \pm 11.0$ & $264.6 \pm 13.0$ & $306.1 \pm 16.4$ \\
\hline LPLC & $135.5 \pm 7.2$ & $232.4 \pm 11.3$ & $270.7 \pm 12.0$ & $308.1 \pm 14.6$ \\
\hline \multicolumn{5}{|c|}{ Daily weight gain $(\mathrm{kg} / \mathrm{d})$} \\
\hline Control & $0.613 \pm 0.03$ & $0.141 \pm 0.01$ & $0.346 \pm 0.03$ & $0.617 \pm 0.05$ \\
\hline HPHC & $0.817 \pm 0.03$ & $0.503 \pm 0.04$ & $0.458 \pm 0.04$ & $0.796 \pm 0.03$ \\
\hline HPLC & $0.761 \pm 0.03$ & $0.417 \pm 0.02$ & $0.433 \pm 0.04$ & $0.746 \pm 0.01$ \\
\hline LPHC & $0.829 \pm 0.03$ & $0.369 \pm 0.04$ & $0.477 \pm 0.03$ & $0.823 \pm 0.06$ \\
\hline LPLC & $0.816 \pm 0.03$ & $0.358 \pm 034$ & $0.424 \pm 0.03$ & $0.813 \pm 0.03$ \\
\hline
\end{tabular}
ADG than supplemented young bulls in all phases and consequently had lower initial weight in phases 2,3 , and 4

Table 3. Initial body weight and daily weight gain (mean \pm SE) of animals from the nutrional plans in each phase

SE, standard error; HPHC, high protein and high carbohydrate supplement; HPLC, high protein and low carbohydrate supplement; LPHC, low protein and high carbohydrate supplement; LPLC, low protein and low carbohydrate supplement. 
(Table 3); see more details in Valente et al. (2013a). The intake was expressed as a function of body weight, this allowed a suitable comparison between treatments during the experimental phases even if the body weights were different.
The average milk intake by calves was $6.2 \mathrm{~kg} / \mathrm{d}$. Nonsupplemented young bulls had lower $(\mathrm{p}<0.05) \mathrm{CP}$ intake than young bulls receiving the high protein (HPHC and HPLC) supplements in every phase and lower than all supplemented young bulls in phases 1 and 2 (Table 4).

Table 4. Least square means for intake of supplement, total dry matter (DM), dry matter of pasture (DMP) and total digestible nutrients (TDN)

\begin{tabular}{|c|c|c|c|c|c|}
\hline \multirow{2}{*}{ Nutritional plan } & \multicolumn{4}{|c|}{ Production phase } & \multirow{2}{*}{ SE } \\
\hline & Phase 1 & Phase 2 & Phase 3 & Phase 4 & \\
\hline \multicolumn{6}{|c|}{ Supplement intake (kg) } \\
\hline Control & - & - & - & - & - \\
\hline HPHC & 0.734 & 0.946 & 0.996 & 1.758 & 0.09 \\
\hline HPLC & 0.344 & 0.504 & 0.511 & 0.771 & 0.10 \\
\hline LPHC & 0.671 & 0.934 & 0.856 & 1.768 & 0.12 \\
\hline LPLC & 0.353 & 0.449 & 0.477 & 0.793 & 0.12 \\
\hline \multicolumn{6}{|l|}{$\mathrm{DM}(\mathrm{g} / \mathrm{kg} \mathrm{BW})$} \\
\hline Control & $14.68^{\mathrm{Bb}}$ & $13.14^{\mathrm{Bb}}$ & $21.63^{\mathrm{Ba}}$ & $19.63^{\mathrm{a}}$ & 0.59 \\
\hline HPHC & $17.58^{\mathrm{Ac}}$ & $19.30^{\mathrm{Abc}}$ & $23.10^{\mathrm{ABa}}$ & $20.59^{\mathrm{ab}}$ & 0.57 \\
\hline HPLC & $18.28^{\mathrm{Ab}}$ & $16.20^{\mathrm{Ab}}$ & $24.78^{\mathrm{Aa}}$ & $21.91^{\mathrm{a}}$ & 0.60 \\
\hline LPHC & $17.06^{\mathrm{ABb}}$ & $17.50^{\mathrm{Ab}}$ & $23.69^{\mathrm{ABa}}$ & $19.52^{\mathrm{b}}$ & 0.60 \\
\hline LPLC & $15.66^{\mathrm{ABc}}$ & $16.70^{\mathrm{Abc}}$ & $23.44^{\mathrm{ABa}}$ & $18.87^{\mathrm{ab}}$ & 0.58 \\
\hline $\mathrm{SE}$ & 0.99 & 1.10 & 1.17 & 1.35 & \\
\hline \multicolumn{6}{|l|}{$\mathrm{DMP}(\mathrm{g} / \mathrm{kg} \mathrm{BW})$} \\
\hline Control & $10.69^{\mathrm{Aba}}$ & $13.14^{\mathrm{b}}$ & $21.62^{\mathrm{a}}$ & $19.63^{\mathrm{Aa}}$ & 0.53 \\
\hline HPHC & $9.53^{\mathrm{Bc}}$ & $15.70^{\mathrm{b}}$ & $19.9^{\mathrm{a}}$ & $15.98^{\mathrm{Bab}}$ & 0.51 \\
\hline HPLC & $12.74^{\mathrm{Ac}}$ & $14.30^{\mathrm{bc}}$ & $23.01^{\mathrm{a}}$ & $19.74^{\mathrm{Ab}}$ & 0.54 \\
\hline LPHC & $9.95^{\mathrm{Bc}}$ & $13.96^{\mathrm{b}}$ & $20.73^{\mathrm{a}}$ & $15.18^{\mathrm{Bb}}$ & 0.54 \\
\hline LPLC & $9.82^{\mathrm{Bd}}$ & $14.96^{\mathrm{c}}$ & $21.75^{\mathrm{a}}$ & $17.93^{\mathrm{ABb}}$ & 0.52 \\
\hline SE & 0.90 & 0.99 & 1.05 & 1.12 & \\
\hline \multicolumn{6}{|l|}{$\operatorname{NDF}(g / k g ~ B W)$} \\
\hline Control & $7.48^{\mathrm{ABb}}$ & $8.87^{\mathrm{Bb}}$ & $13.40^{\mathrm{ABa}}$ & $11.70^{\mathrm{ABa}}$ & 0.34 \\
\hline Plan 1 & $7.01^{\mathrm{ABc}}$ & $10.76^{\mathrm{Aab}}$ & $12.50^{\mathrm{Ba}}$ & $10.05^{\mathrm{ABb}}$ & 0.33 \\
\hline Plan 2 & $8.62^{\mathrm{Ac}}$ & $9.99^{\mathrm{ABc}}$ & $14.70^{\mathrm{Aa}}$ & $12.04^{\mathrm{Ab}}$ & 0.35 \\
\hline Plan 3 & $6.80^{\mathrm{Bc}}$ & $9.98^{\mathrm{ABb}}$ & $13.31^{\mathrm{ABa}}$ & $9.64^{\mathrm{Bb}}$ & 0.35 \\
\hline Plan 4 & $6.90^{\mathrm{Bc}}$ & $10.40^{\mathrm{ABb}}$ & $13.30^{\mathrm{ABa}}$ & $11.28^{\mathrm{ABab}}$ & 0.34 \\
\hline $\mathrm{SE}$ & 0.57 & 0.63 & 0.67 & 0.72 & \\
\hline \multicolumn{6}{|l|}{$\mathrm{CP}(\mathrm{g} / \mathrm{kg} \mathrm{BW})$} \\
\hline Control & $1.90^{\mathrm{Cb}}$ & $0.82^{\mathrm{Cc}}$ & $2.95^{\mathrm{Ba}}$ & $2.16^{\mathrm{Bb}}$ & 0.09 \\
\hline HPHC & $3.26^{\mathrm{Aab}}$ & $2.15^{\mathrm{Ac}}$ & $3.60^{\mathrm{Aa}}$ & $2.97^{\mathrm{Ab}}$ & 0.08 \\
\hline HPLC & $3.24^{\mathrm{Aa}}$ & $1.86^{\mathrm{Ab}}$ & $3.54^{\mathrm{Aa}}$ & $3.12^{\mathrm{Aa}}$ & 0.09 \\
\hline LPHC & $2.40^{\mathrm{Bb}}$ & $1.36^{\mathrm{Bc}}$ & $2.87^{\mathrm{Ba}}$ & $2.26^{\mathrm{Bb}}$ & 0.09 \\
\hline LPLC & $2.51^{\mathrm{Bb}}$ & $1.36^{\mathrm{Bc}}$ & $3.21^{\mathrm{ABa}}$ & $2.25^{\mathrm{Bb}}$ & 0.09 \\
\hline SE & 0.15 & 0.16 & 0.17 & 0.18 & \\
\hline \multicolumn{6}{|l|}{ TDN (g/kg BW) } \\
\hline Control & $11.04^{\mathrm{Ba}}$ & $7.44^{\mathrm{Cb}}$ & $12.43^{\mathrm{Ba}}$ & $11.41^{\mathrm{a}}$ & 0.39 \\
\hline HPHC & $13.91^{\mathrm{Aa}}$ & $11.88^{\mathrm{Ab}}$ & $14.99^{\mathrm{Aa}}$ & $13.18^{\mathrm{a}}$ & 0.37 \\
\hline HPLC & $13.48^{\mathrm{ABab}}$ & $9.85^{\mathrm{ABc}}$ & $15.77^{\mathrm{Aa}}$ & $13.49^{\mathrm{b}}$ & 0.40 \\
\hline LPHC & $12.11^{\mathrm{ABab}}$ & $10.55^{\mathrm{ABb}}$ & $14.19^{\mathrm{ABa}}$ & $12.05^{\mathrm{ab}}$ & 0.40 \\
\hline LPLC & $11.87^{\mathrm{Bb}}$ & $9.69^{\mathrm{Bc}}$ & $14.26^{\mathrm{ABa}}$ & $12.52^{\mathrm{ab}}$ & 0.38 \\
\hline SE & 0.66 & 0.73 & 0.77 & 0.82 & \\
\hline
\end{tabular}

HPHC, high protein and high carbohydrate supplement; HPLC, high protein and low carbohydrate supplement; LPHC, low protein and high carbohydrate supplement; LPLC, low protein and low carbohydrate supplement; SE, standard error; BW, body weight; NDF, neutral detergent fiber; CP, crude protein. ${ }^{\text {abc }}$ Different subscript lowercase letters within a row denote significant difference according to period $(\mathrm{p}<0.05)$ and different subscript capital letters within a column denote significant difference according to nutritional plans $(\mathrm{p}<0.05)$. 
Only young bulls that received supplements with high protein (HPHC and HPLC) had greater $(\mathrm{p}<0.05)$ intake of DM than control young bulls in the suckling phase (phase 1). However, only the supplemented young bulls with HPHC provided had an intake of dry matter of pasture (DMP) similar $(p>0.05)$ to control young bulls and an increased $(p<0.05)$ intake of TDN (Table 4). Thus, the HPHC increased the amount of energy available for animal metabolism without decreasing the pasture use.

Although supplemented and non-supplemented young bulls had similar intakes of DMP $(p>0.05)$ in the dry season (phase 2), all supplemented young bulls had greater $(\mathrm{p}<0.05)$ intakes of DM and TDN than non-supplemented. However, only animals from the HPHC group showed an increase $(p<0.05)$ in the intake of NDF (Table 4).

Supplementation did not affect $(p>0.05)$ intake of pasture in the dry-rainy transition season (phase 3 ). However, only young bulls from the HPLC group had greater $(\mathrm{p}<0.05) \mathrm{DM}$ intake and only young bulls from high protein treatments (HPHC and HPLC) had intakes of TDN greater $(p<0.05)$ than non-supplemented animals.

Significant differences were not found $(p>0.05)$ for the intake of DM and TDN between the nutritional plans in the rainy season (phase 4). Moreover, there was a tendency of increasing intake of TDN with high protein supplements (HPHC, $p=0.14$; HPLC, $p=0.08$ ) (Table 4). Pasture intake was lower $(\mathrm{p}<0.05)$ compared to nutritional plans with high carbohydrate (HPHC and LPHC) in comparison with nutritional plans with low carbohydrate (HPLC and LPLC) and with the control in rainy season. In addition, animals that had LPHC $(15 \% \mathrm{CP})$ had lower $(\mathrm{p}<0.05)$ intakes of NDF than animals on HPLC (55\% CP).

The HPHC provided greater $(\mathrm{p}<0.05)$ digestibility of DM and content of TDN than the other supplements during the suckling phase. On other hand, LPHC provided lower $(\mathrm{p}<0.05)$ digestibility of NDF and TDN content than control

Table 5. Least square means for digestibility of dry matter (DM), neutral detergent fiber corrected for ash and protein (apNFD), crude protein (CP) and perceptual value of total digestible nutrients (TDN)

\begin{tabular}{|c|c|c|c|c|c|}
\hline \multirow{2}{*}{ Nutritional plan } & \multicolumn{4}{|c|}{ Production phase } & \multirow{2}{*}{ SE } \\
\hline & Phase 1 & Phase 2 & Phase 3 & Phase 4 & \\
\hline \multicolumn{6}{|l|}{$\overline{\mathrm{DM}}(\%)$} \\
\hline Control & $66.45^{\mathrm{Ba}}$ & $56.69^{\mathrm{Cb}}$ & $57.95^{\mathrm{Db}}$ & $58.70^{\mathrm{Cb}}$ & 0.42 \\
\hline HPHC & $70.28^{\mathrm{Aa}}$ & $62.63^{\mathrm{Ac}}$ & $66.37^{\mathrm{Ab}}$ & $65.56^{\mathrm{Ab}}$ & 0.41 \\
\hline HPLC & $67.31^{\mathrm{Ba}}$ & $61.78^{\mathrm{Ab}}$ & $63.59^{\mathrm{Bb}}$ & $63.29^{\mathrm{ABb}}$ & 0.43 \\
\hline LPHC & $67.26^{\mathrm{Ba}}$ & $62.05^{\mathrm{Abc}}$ & $59.00^{\mathrm{CDc}}$ & $62.76^{\mathrm{Bb}}$ & 0.41 \\
\hline LPLC & $68.13^{\mathrm{Ba}}$ & $59.63^{\mathrm{Bc}}$ & $60.37^{\mathrm{Cc}}$ & $64.04^{\mathrm{Ab}}$ & 0.41 \\
\hline $\mathrm{SE}$ & 0.71 & 0.79 & 0.85 & 0.90 & \\
\hline \multicolumn{6}{|l|}{ apNDF (\%) } \\
\hline Control & $67.52^{\mathrm{Bb}}$ & $73.43^{\mathrm{Aa}}$ & $72.62^{\mathrm{BCa}}$ & $63.86^{\mathrm{BCc}}$ & 0.40 \\
\hline HPHC & $68.34^{\mathrm{ABb}}$ & $74.19^{\mathrm{Aa}}$ & $75.38^{\mathrm{Aa}}$ & $64.41^{\mathrm{BCc}}$ & 0.39 \\
\hline HPLC & $67.86^{\mathrm{ABc}}$ & $70.85^{\mathrm{Bb}}$ & $74.97^{\mathrm{ABa}}$ & $65.38^{\mathrm{ABd}}$ & 0.42 \\
\hline LPHC & $63.96^{\mathrm{Cc}}$ & $67.90^{\mathrm{Cb}}$ & $70.38^{\mathrm{Ca}}$ & $62.79^{\mathrm{Cc}}$ & 0.39 \\
\hline LPLC & $69.62^{\mathrm{A}}$ & $69.17^{\mathrm{BC}}$ & $70.78^{\mathrm{C}}$ & $67.74^{\mathrm{A}}$ & 0.39 \\
\hline SE & 0.73 & 0.81 & 0.81 & 0.87 & \\
\hline \multicolumn{6}{|l|}{$\mathrm{CP}(\%)$} \\
\hline Control & $71.74^{\mathrm{Ba}}$ & $39.58^{\mathrm{Dd}}$ & $60.97^{\mathrm{Cc}}$ & $67.54^{\mathrm{Cb}}$ & 0.61 \\
\hline HPHC & $78.51^{\mathrm{Aa}}$ & $61.78^{\mathrm{Ad}}$ & $68.34^{\mathrm{Ac}}$ & $74.78^{\mathrm{Ab}}$ & 0.60 \\
\hline HPLC & $77.81^{\mathrm{Aa}}$ & $65.71^{\mathrm{Bc}}$ & $64.20^{\mathrm{Bc}}$ & $70.87^{\mathrm{BCb}}$ & 0.63 \\
\hline LPHC & $71.40^{\mathrm{Ba}}$ & $53.01^{\mathrm{Cc}}$ & $55.87^{\mathrm{Dc}}$ & $68.00^{\mathrm{BCb}}$ & 0.60 \\
\hline LPLC & $74.78^{\mathrm{Aa}}$ & $55.74^{\mathrm{Cc}}$ & $59.74^{\mathrm{BCb}}$ & $71.46^{\mathrm{ABa}}$ & 0.61 \\
\hline SE & 1.10 & 1.23 & 1.23 & 1.31 & \\
\hline \multicolumn{6}{|l|}{ TDN (\%) } \\
\hline Control & $75.39^{\mathrm{Ba}}$ & $56.69^{\mathrm{Bb}}$ & $59.48^{\mathrm{Bb}}$ & $57.98^{\mathrm{Bb}}$ & 0.79 \\
\hline HРHC & $79.62^{\mathrm{Aa}}$ & $61.50^{\mathrm{Ab}}$ & $64.81^{\mathrm{Ab}}$ & $64.04^{\mathrm{Ab}}$ & 0.77 \\
\hline HPLC & $75.64^{\mathrm{Ba}}$ & $60.88^{\mathrm{ABb}}$ & $63.62^{\mathrm{ABb}}$ & $61.65^{\mathrm{ABb}}$ & 0.81 \\
\hline LPHC & $71.00^{\mathrm{Ca}}$ & $60.23^{\mathrm{ABb}}$ & $59.89^{\mathrm{Bb}}$ & $61.42^{\mathrm{ABb}}$ & 0.77 \\
\hline LPLC & $75.60^{\mathrm{Ba}}$ & $57.86^{\mathrm{ABc}}$ & $60.47^{\mathrm{Bbc}}$ & $62.91^{\mathrm{ABb}}$ & 0.79 \\
\hline SE & 1.42 & 1.60 & 1.60 & 1.70 & \\
\hline
\end{tabular}

$\overline{\mathrm{HPHC}}$, high protein and high carbohydrate supplement; HPLC, high protein and low carbohydrate supplement; LPHC, low protein and high carbohydrate supplement; LPLC, low protein and low carbohydrate supplement; SE, standard error.

${ }^{a b c}$ Different subscript lowercase letters within a row denote significant difference according to period $(\mathrm{p}<0.05)$ and different subscript capital letters within a column denote significant difference according to nutritional plans $(\mathrm{p}<0.05)$. 
and the other supplements (Table 5).

Young bulls from control and HPHC groups had greater (p>0.05) NDF digestibility in dry season (phase 2). However, the control group had lower $(p<0.05)$ DM digestibility. In addition, the nutritional plan with LPHC had lower NDF digestibility, but differences in TDN content were not observed $(p>0.05)$ between supplemented young bulls (Table 5).

The young bulls that received nutritional plans with high protein supplements (HPHC and HPLC) had greater $(\mathrm{p}<0.05)$ digestibility of DM and NDF and greater $(\mathrm{p}<0.05)$ TDN content than other nutritional plans in the dry-rainy transition season (phase 3). Although the LPLC supplement provided greater $(\mathrm{p}<0.05) \mathrm{DM}$ digestibility than control, the supplements with low protein (LPHC and LPLC) did not differ $(p>0.05)$ in NDF digestibility and TDN content in comparison with control (Table 5).

The supplemented young bulls had greater $(\mathrm{p}<0.05) \mathrm{DM}$ digestibility than control young bulls in the rainy season (phase 4). Moreover, nutritional plans HPHC and LPLC had the greatest $(p<0.05)$ NDF digestibility. However, only HPHC had greater $(\mathrm{p}<0.05)$ TDN content than the control group.

Comparing the productive phases, greater $(\mathrm{p}<0.05) \mathrm{CP}$ intake was observed in phase 3 , followed by phases 1 and 4 , and it was lower $(\mathrm{p}<0.05)$ in phase 2 . Most nutritional plans had similar $(p>0.05)$ DM intake in phases 3 and 4 , with the exception of the animals from LPHC that had greater $(\mathrm{p}<0.05) \mathrm{DM}$ intake in phase 3 than phase 4 . Intake of TDN was similar $(p>0.05)$ between phases 1,3 , and 4 , and lower $(\mathrm{p}<0.05)$ in phase 2. However, pasture intake in phase 3 was greater $(\mathrm{p}<0.05)$ than in phase 4 , and the lowest $(\mathrm{p}<0.05)$ pasture intake was observed in phases 1 and 2 (Table 4).

The greatest $(\mathrm{p}<0.05)$ digestibility of DM and CP was in the suckling phase (phase 1, rainy-to-dry transition season), followed by phase 4 (rainy season) and phase 3 (dry to rainy transition), and it was lowest $(\mathrm{p}<0.05)$ in phase 2 (dry season). Only animals from the HPHC group had greater $(\mathrm{p}<0.05) \mathrm{DM}$ digestibility in phase 3 than in phase 2 . Although differences were not found $(p<0.05)$ in DM digestibility between phases 3 and 4 supplemented with high protein (HPHC and HPLC), supplements with low protein (LPHC and LPLC) had lower DM digestibility $(\mathrm{p}<0.05)$ in phase 3 than in phase 4.

\section{DISCUSSION}

Although calves had high milk intake $(6.2 \mathrm{~kg} / \mathrm{d})$ and the pasture had moderate $\mathrm{CP}$ content $(8.8 \% \mathrm{CP}$, Table 2$)$, the intake of high protein supplements (HPHC and HPLC) increased the DM intake, which agrees with the theory that there is a response with supplementing protein to cattle grazing tropical pastures even when the $\mathrm{CP}$ in diet seems adequate (Detmann et al., 2010). The amino acid profile of $\mathrm{CP}$ in the diet, as well the balance between amino acids absorbed and metabolizable energy availability, may determine the metabolic use of metabolites and feed intake (Greenwood and Titgemeyer, 2000). On the other hand, ruminal microorganisms have a specific nutrient requirement; thus, protein and energy balance in rumen may affect nutritional characteristics (Souza et al., 2010). Therefore, animals that received HPHC would have the best profile of protein, balance protein and energy, and consequently had the best intake of pasture, TDN, and DM digestibility. In contrast, energetic supplements (LPHC) decreased fiber digestibility. The reduction of fiber use by cattle grazing on tropical pastures receiving energetic supplements occurs mainly due to the modification of the microorganism population (Souza et al., 2010; Carvalho et al., 2011).

The results obtained in the suckling phase, where high protein supplement provided the best response by calves, seem contradictory with supplement type adopted by traditional production systems in tropical pastures, which commonly utilizes information from temperate conditions, where energetic supplements are typically used (14\% to $16 \%$ CP) in creep feeding (Tarr et al., 1994; Ralston et al., 2005). Similar to this assay, Sampaio et al. (2010) found greater intake and digestibility of DM in calves that received protein-energetic supplements than in calves that received energetic supplements. Thus, the interaction of supplements and basal diet (tropical or temperate pasture) strongly affect the nutritional parameters.

The extraction of energy from fibrous carbohydrates in the dry season is limited by the lack of nitrogen compounds to synthesize the enzymatic systems of ruminal microorganisms (Detmann et al., 2009; Valente et al., 2011a). Protein supplementation increases degradation rate and decreases discrete latency time of potential digestible NDF in rumen (Detmann et al., 2011). Oliveira et al. (2010) observed increases in DM degradability, degradation of NDF and DM, and passage rate with protein supplementation. However, in this work differences occurred between the protein supplements in the degradation of dietetic fractions. When carbohydrate is supplied together with protein to ruminants, the efficiency of nitrogen assimilation is increased (Detmann et al., 2010). Thus, simplifications of the nutritional process considering only CP supply may result in inadequate information; the balance of protein and energy in diets determines the nutritional effects.

Energetic supplements usually increase the amount of total energy intake, mainly by directly supplying energy from supplements, since normally there is no increase in pasture intake (Figueiredo et al., 2011). Thus, the energetic supplement (LPHC, $15 \%$ CP) provided lower fiber 
digestibility with similar TDN intake when compared to the other supplements.

Although pasture had high protein content $(12.1 \% \mathrm{CP})$ in the dry-to-rainy transition season (Table 2), the supplement with high protein (HPHC) increased DM intake (Table 4), digestibility of DM and NDF and TDN content in diet (Table 5). This fact may be due to protein supplementation improving the population of cellulolytic bacteria in the rumen (Carvalho et al., 2011). The most limiting substrate to cellulolytic bacteria growth is nitrogen (Carvalho et al., 2011); because most protein in tropical plants is slowly available or non-available to bacteria in rumen (Detmann et al., 2010), therefore, protein supplementation can increase cellulolytic bacteria growth.

Even though supplementation provided increases in DM digestibility during the rainy season, all nutritional plans had similar intakes of DM and TDN. Although some authors (Nascimento et al., 2010; Figueiredo et al., 2011) observed increases in TDN intake without changes in DM intake due to the many factors that make treatment effects less visible over cattle on pasture condition, other authors (Figueiredo et al., 2008; Barros et al., 2011) did find differences.

Tropical pastures have a ratio energy: protein above animals demand in the rainy season, implying that a relative excess of energy exists in relation to protein (Detmann et al., 2010). Thus, protein supplementation may improve the balance ratio of energy: protein closer to the metabolic demands of animal and increase energy intake by metabolic control.

It was observed that the negative effects of energetic supplement on pasture intake were more intense in the rainy season than in the dry-to-rainy transition season. Carbohydrate supplementation may improve microbial assimilation of nitrogenous compounds in the rumen when there is high availability of $\mathrm{N}$ (Souza et al., 2010); thus, in situations where forage has a high CP content (as during the dry-to-rainy season transition), the negative effects of energetic supplementation on the intake and digestibility of pasture are less intense.

The lower pasture intake observed in phases 1 and 2 for all nutritional plans compared to phases 3 and 4 were the result of a distinct process. In the suckling phase, the rumens of calves are still in development, and they are less able to utilize rough feed; in addition, the greater part of their demands are supplied by milk (Valente et al., 2013b). On other hand, in the dry season, the lower intake of pasture is mainly due to insufficient CP intake that may produce a ruminal deficiency of nitrogen compounds (Figueiras et al., 2010).

The soluble and potentially degradable fractions of carbohydrate and protein, as well as effective degradability of DM, NDF, and CP, vary according to the season (Ortiz et al., 2010). Similarly, passage rate and DM digestibility are influenced by the season (Estrada et al., 2010). Therefore, supplementation may change nutritional availabilities of diet throughout the year. Nutritional plans with low carbohydrate supplements had greater TDN intake during phase 3 than during the other phases, while most nutritional plans had similar TDN intake between phases 1, 3, and 4 . Thus, interactions between supplementary dietetic fractions and basal diet (pasture) determine ruminal (degradation rate and passage rate) and metabolic (animal physiological control) effects on intake and utilization of feed, with different effects from the same supplement in different seasons.

\section{CONCLUSIONS}

Supplementation increases DM intake during the dry, dry-to-rainy transition and rainy-to-dry transition seasons, but not in the rainy season. However, supplementation may improve DM digestibility, even in the rainy season. Supplements with high protein levels (supplying $50 \%$ of the $\mathrm{CP}$ requirement) provide the best nutritional parameters for grazing young bulls in most seasons, increasing intake and digestibility of diet, and these effects are more intense when associated with high carbohydrate levels level (supplying $30 \%$ TDN requirement). On the other hand, supplements with high carbohydrate levels decrease pasture intake during the dry season; however, when associated with low protein levels (supplying $25 \%$ of the $\mathrm{CP}$ requirement), high carbohydrate levels decrease fiber digestibility in most seasons, except for the dry-to-rainy transition season.

\section{ACKNOWLEDGMENTS}

The authors wish to thank the Conselho Nacional de Pesquisa e Desenvolvimento Científico e Tecnológico (CNPq) for financial support.

\section{REFERENCES}

AOAC. 1999. Official Methods of Analysis (16th ed.). Association of Official Analytical Chemistry, Inc. Washington, DC, USA.

Barros, L. V., M. F. Paulino, S. C. Valadares Filho, E. Detmann, F. G. Silva, E. E. L. Valente, S. A. Lopes, and L. S. Martins. 2011. Replacement of soybean meal by cottonseed meal $38 \%$ in multiple supplements for grazing beef heifers. Rev. Bras. Zootec. 40:852-859.

Carvalho, I. P. C., E. Detmann, H. C. Mantovani, M. F. Paulino, S. C. Valadares Filho, V. A. C. Costa, and D. I. Gomes. 2011. Growth and antimicrobial activity of lactic acid bacteria from rumen fluid according to energy or nitrogen source. Rev. Bras. Zootec. 40:1260-1265.

Costa, V. C., E. Detmann, M. F. Paulino, S. C. Valadares Filho, L. T. Henriques, I. P. C. Carvalho, and T. N. P. Valente. 2011. 
Intake and rumen dynamics of neutral detergent fiber in grazing cattle supplemented with non-protein nitrogen and, or true protein during the rainy season. Rev. Bras. Zootec. 40:2805-2814.

Detmann, E., M. F. Paulino, H. C. Mantovani, S. C. Valadares Filho, C. B. Sampaio, M. A. Souza, I. Lazzarini, and K. S. C. Detmann. 2009. Parameterization of ruminal fibre degradation in low-quality tropical forage using Michaelis-Menten kinetics. Livest. Sci. 126:136-146.

Detmann, E., M. F. Paulino, and S. C. Valadares Filho. 2010. Optimizing the use of basal forage resources. In: Proceedings of 7rd Symposium of Beef Cattle Production. Departamento de Zootecnia, UFV, Viçosa, Brazil. 191-240.

Detmann, E., A. C. Queiroz, K. Zorzi, H. C. Mantovani, G. F. Bayão, and M. P. C. Gomes. 2011. In vitro degradation of neutral detergent fiber of low-quality tropical forage according to supplementation with true protein and (or) non-protein nitrogen. Rev. Bras. Zootec. 40:1272-1279.

Estrada, O. R., M. M. Ortiz, E. H. Torres, J. N. G. Reyes, and J. Reyes. 2010. Influence of season on chemical composition of diet selected by steers grazing. J. Anim. Vet. Adv. 9:2969-2972.

Figueiras, J. F., E. Detmann, M. F. Paulino, T. N. P. Valente, S. C. Valadares Filho, and I. Lazzarini. 2010. Intake and digestibility in cattle under grazing supplemented with nitrogenous compounds during dry season. Rev. Bras. Zootec. 39:13031312 .

Figueiredo, D. M., M. F. Paulino, E. Detmann, E. H. B. Kling, S. C. Valadares Filho, and M. A. Souza. 2008. Protein sources of in multiple supplements for cattle on pasture during the rainy season. Rev. Bras. Zootec. 37:2222-2232.

Figueiredo, D. M., M. F. Paulino, M. F. L. Sales, S. C. Valadares Filho, E. Detmann, and L. V. Barros. 2011. Levels of ground corn supplied to beef heifers at pasture during the rainy season: productive performance, intake, digestibility and microbial efficiency. Rev. Bras. Zootec. 40:2523-2531.

Forbes, J. M. 2007. A personal view of how ruminant animals control their intake and choice of food: minimal total discomfort. Nutr. Res. Rev. 20:132-146.

Goes, R. H. T. B., A. B. Mancio, R. P. Lana, P. R. Cecon, D. D. Alves, T. B. Freitas, and K. C. S. Brabes. 2010. Protein and energy supplementation for growing steers, in dry season. Rev. Bras. Saúde Prod. Anim. 11:1081-1094.

Greenwood, R. H. and E. C. Titgemeyer. 2000. Limiting amino acids for growing Holstein steer limit-fed soybean hull-based diets. J. Anim. Sci. 78:1997-2004.

Kaps, M. and W. R. Lamberson. 2004. Biostatistics for Animal Science. CABI Publishing, Cambridge, MA, USA.

Licitra, G., T. M. Hernandez, and P. J. Van Soest. 1996. Standardization of procedures for nitrogen fractionation of ruminant feeds. Anim. Feed Sci. Technol. 57:347-358.

Mertens, D. R. 2002. Gravimetric determination of amylase treated neutral detergent fiber in feeds with refluxing in beakers or crucibles: Collaborative study. J. AOAC Int. 85:1217-1240.
Nascimento, M. L., M. F. Paulino, E. Detmann, M. I. Leão, S. C. Valadares Filho, and L. T. Henriques. 2010. Energy sources in multiple supplement to grazing steers at rain season. Rev. Bras. Zootec. 39:861-872.

Oliveira, L. O. F., E. O. S. Saliba, L. C. Gonçalves, I. Borges, P. A. B. Miranda, and M. P. F. Fialho. 2010. In situ digestibility and ruminal kinetics of steers receiving protein supplementation on pasture. Rev. Bras. Zootec. 39:1328-1335.

Ortiz, M. M., O. R. Estrada, E. H. Torres, E. G. Órnelas, and H. G. Garcia. 2010. Annual and seasonal changes in ruminal degradability of diets by grazing steers in native range. Agric. J. 5:259-263.

Ralston, B. J., M. E. Olson, K. C. Garossino, T. A. McAllister, D. N. Milligan, and B. M. A. Genswein. 2005. Individual free choice creep feed intake by suckling calves on range. Can. J. Anim. Sci. 85:401-404.

Sampaio, A. A. M., A. R. M. Fernandes, H. Wignez, G. M. Ribeiro, E. A. Oliveira, and T. M. Silva. 2010a. Effect of supplementation on nutriente digestibility and performance of lacting calves fed with Brachiaria brizantha pastures. Acta Sci. Anim. Sci. 32:63-68.

Souza, M. A., E. Detmann, M. F. Paulino, C. B. Sampaio, I. Lazzarini, and S. C. Valadares Filho. 2010. Intake, digestibility and rumen dynamics of neutral detergent fiber in cattle fed low-quality tropical forage and supplemented with nitrogen and/or starch. Trop. Anim. Health Prod. 42:1299-1310.

Tarr, S. L., D. B. Fauçkner, D. D. Buskirk, F. A. Ireland, D. F. Parrett, and L. L. Berger. 1994. The value of creep feeding during the last 84,56 or 28 days prior to weaning on growth performance of nursing calves grazing endophyte-infected tall fescues. J. Anim. Sci. 72:1084-1094.

Valadares Filho, S. C., P. V. R. Paulino, and K. A. Magalhães. 2006. Requirements of zebu cattle and feed composition table BR CORTE. Viçosa, MG: UFV, Suprema Gráfica Ltda, 142 p.

Valente, E. E. L., M. F. Paulino, E. Detmann, S. C. Valadares Filho, L. V. Barros, T. S. Acedo, V. R. M. Couto, and A. S. Lopes. 2011a. Levels of multiple supplements or nitrogen salt for beef heifers in pasture during the dry season. Rev. Bras. Zootec. 40:2011-2019.

Valente, T. N. P., E. Detmann, A. C. Queiroz, S. C. Valadares Filho, D. I. Gomes, and J. F. Figueiras. 2011b. Evaluation of ruminal degradability profiles of forage using bags made from different textiles. Rev. Bras. Zootec. 40:2565-2573.

Valente, E. E. L., M. F. Paulino, E. Detmann, S. C. Valadares Filho, and S. A. Lopes. 2013a. Performance of young bulls supplemented with different relation of protein and carbohydrate from suckling phase until slaughter in tropical pasture. J. Anim. Plant Sci. 18:2711-2722.

Valente, E. E. L., M. F. Paulino, E. Detmann, S. C. Valadares Filho, L. V. Barros, N. F. Paula, S. A. Lopes, D. M. Almeida, and L. S. Martins. 2013b. Effect of calves supplementation on performance, nutritional and behavioral characteristics of their dams. Trop. Anim. Health Prod. 45, 487-495.

Van Soest, P. J. and J. B. Robertson. 1985. Analysis of forages and fibrous foods Ithaca: Cornell University. Cornell University Ithaca NY, USA. 202 p. 